\title{
GEOGRAPHIC INFORMATION SYSTEM APPROACH FOR PLAY PORTFOLIOS TO IMPROVE OIL PRODUCTION IN THE ILLINOIS BASIN
}

\author{
Final Technical Progress Report \\ Reporting Period Start Date: February 28, 2002 \\ Reporting Period Ending Date Sept. 30, 2004 \\ Principal Author: Beverly Seyler and John Grube \\ Date Report Issued December 10, 2004 \\ DOE Award Number: DEFC26-02NT15132
}

Submitting Organization:

The Board of Trustees of the University of Illinois

Grants and Contracts Administration 109 Coble Hall

801 South Wright Street

Champaign, IL 61820-6242

Principal Investigator: Beverly Seyler

Illinois State Geological Survey

615 East Peabody Drive

Champaign, IL 61820 


\section{Disclaimer}

This report was prepared as an account of work sponsored by an agency of the United States Government. Neither the United States Government nor any agency thereof, nor any of their employees, makes any warranty, expressed or implied, or assumes any legal liability or responsibility for the accuracy, completeness, or usefulness of any information, apparatus, product, or process disclosed, or represents that its use would not infringe privately owned rights. Reference herein to a specific commercial product, process, or service by trade name, trademark, manufacturer, or otherwise does not necessarily constitute or imply its endorsement, recommendation, or favoring by the United States Government or any agency thereof. The views and opinions of authors expressed herein do not necessarily state or reflect those of the United States Government or any agency thereof. 


\section{Abstract}

Oil and gas have been commercially produced in Illinois for over 100 years. Existing commercial production is from more than fifty-two named pay horizons in Paleozoic rocks ranging in age from Middle Ordovician to Pennsylvanian. Over 3.2 billion barrels of oil have been produced. Recent calculations indicate that remaining mobile resources in the Illinois Basin may be on the order of several billion barrels. Thus, large quantities of oil, potentially recoverable using current technology, remain in Illinois oil fields despite a century of development. Many opportunities for increased production may have been missed due to complex development histories, multiple stacked pays, and commingled production which makes thorough exploitation of pays and the application of secondary or improved/enhanced recovery strategies difficult. Access to data, and the techniques required to evaluate and manage large amounts of diverse data are major barriers to increased production of critical reserves in the Illinois Basin. These constraints are being alleviated by the development of a database access system using a Geographic Information System (GIS) approach for evaluation and identification of underdeveloped pays.

The Illinois State Geological Survey has developed a methodology that is being used by industry to identify underdeveloped areas (UDAs) in and around petroleum reservoirs in Illinois using a GIS approach. This project utilizes a statewide oil and gas Oracle $^{\circledR}$ database to develop a series of Oil and Gas Base Maps with well location symbols that are color-coded by producing horizon. These maps are presented in scalable format on an Arc/IMS website at http://meltwater.isgs.uiuc.edu/website/iloil arcmap/viewer.htm. Producing horizons are displayed as layers and can be selected as separate or combined layers that can be turned on and off. Map views can be customized to serve individual needs and page size maps can be printed.

A core analysis database with over 168,000 entries has been compiled and assimilated into the ISGS Enterprise Oracle database. Maps of wells with core data have been generated. Data from over 1,700 Illinois waterflood units and waterflood areas have been entered into an Access ${ }^{\circledR}$ database. The waterflood area data has also been assimilated into the ISGS Oracle database for mapping and dissemination on the ArcIMS website. Formation depths for the Beech Creek Limestone, Ste. Genevieve Limestone and New Albany Shale in all of the oil producing region of Illinois have been calculated and entered into a digital database. Digital contoured structure maps have been constructed, edited and added to the ILoil website as map layers.

This technology/methodology addresses the long-standing constraints related to information access and data management in Illinois by significantly simplifying the laborious process that industry presently must use to identify underdeveloped pay zones in Illinois. 


\section{Table of Contents}

Disclaimer

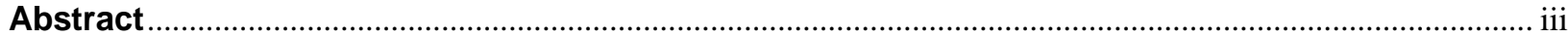

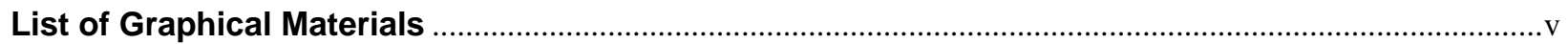

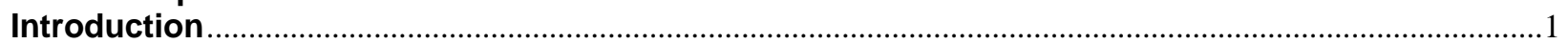

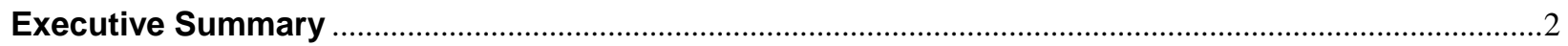

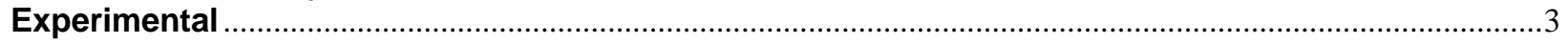

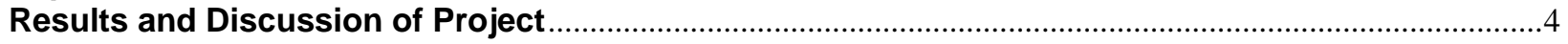

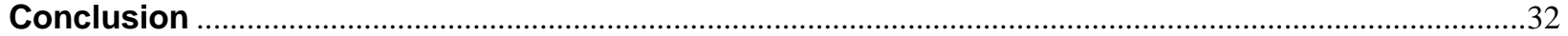

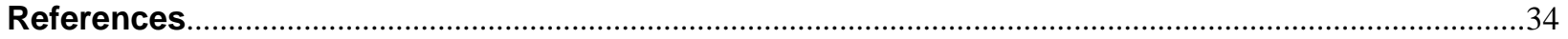

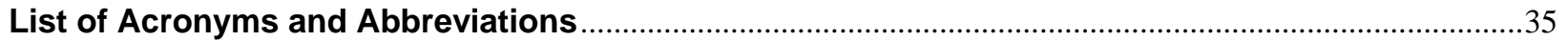




\section{List of Graphical Materials}

Figure 1. Introductory page for ILoil ArclMS website

Figure 2. Description of webpage layers and databases

Figure 3. General instructions and tutorial for using tools to manipulate maps and layers

Figure 4. Display format for interactive website

Figure 5. View of oil fields in portions of Clay and Richland Counties.

Figure 6. Field data table for Clay City Consolidated

Figure 7. Screen capture close-up (Zoom In) shows individual wells.

Figure 8. Greater detail and wells producing from multiple pay zones

Figure 9. Table of individual well data retrieved using select within tool

Figure 10. Map showing select within toolbar and well data table

Figure 11 Map showing decluttering ability of ArcIMS interactive mapping

Figure 12. Map showing ability to selection color coded producing horizons

Figure 13. DOQ base map feature

Figure 14. DOQ base map feature combined with color coded well data

Figure 15. DOQ and color coded data map close-up

Figure 16. USGS Quadrangle base map close-up

Figure 17. Map showing waterflood units and waterflood leases with data

Figure 18. Wells with core analysis data for the Cypress Sandstone

Figure 19. Wells with core analysis data of the Aux Vases Sandstone

Figure 20. Wells with core analysis data from the Ste. Genevieve Formation

Figure 21. WebTrends statistics for ILoil website usage. 


\section{Introduction}

Opportunities in Illinois for increased oil production have been overlooked due to complex development histories from over a century of development of multiple stacked pays, heterogeneous reservoirs, and commingled production. Therefore exploitation of pays and application of secondary or improved/enhanced recovery strategies often underperform. The Illinois State Geological Survey (ISGS) has developed a new GIS and Web delivery approach which is being successfully used to identify new fields and bypassed oil in underdeveloped areas.

An interactive map prototype website, first activated in February, 2003 and funded by a Department of Energy (DOE) PUMP (Preferred Upstream Management Practices) award through the National Energy Technology Laboratory (NETL) has enabled easy public access to over a century of well data information. The public can access the website at http://meltwater.isgs.uiuc.edu/website/iloil arcmap/viewer.htm using their Web browser.

Color-coded producing formation maps are available on the website. Maps can be customized for individual needs by activating needed layers. Maps can be scaled using the zoom tool on the menu and can be printed by users. Users are able to label and print customized maps. An upgrade for the website with a front page and tutorial has been completed and added to the website with the installation of the newest version of ESRI ArcIMS software.

New layers providing additional information were added as they were completed. Layers showing current waterflood units have been completed and added to the website. Historical waterflood units are being prepared for inclusion as layers on the website. Data from over 1,700 waterflood units have been entered into an Access database. Structure maps contoured on the Beech Creek and Ste. Genevieve formations were constructed. Formation depths for these formations have been calculated for the oil producing region in Illinois with over 90,000 formation depths entered into a digital database.

An upgrade of the ILoil website was implemented in October, 2004 and offers well status information as well as producing horizon data and allows users to customize maps at desired scales with desired layers and features.

Transfer of this technology has taken place in several venues including PTTC workshops held in February, 2003 and January 29, 2004 at Mt. Vernon, Illinois, and at a presentation with interactive demonstrations at the Illinois Oil and Gas Association annual meeting held on March 5-6, 2004 in Evansville, Indiana and at the Eastern Section AAPG meeting held on October 4, 2004 in Columbus, Ohio. Workshop and meeting attendees provided positive reviews for the website. ISGS staff provides guidance on the use of website features on an individual basis to answer user questions on an on-going basis. Website use has increased as operators become aware of the site and become familiar with its features. A new computer system for downstate operator access was installed at the Illinois Oil and Gas Association office in Mt. Vernon, Illinois in August, 2004. 


\section{Executive Summary}

An interactive map website was activated in February, 2003 and can be accessed at http://meltwater.isgs.uiuc.edu/website/iloil arcmap/viewer.htm. The current ILoil Interactive Map application was implemented with ESRI ArcIMS \#4.0, ArcSDE and Oracle database applications. The purpose of the ILoil website is to enable the public, via their web browser, to access pertinent petroleum exploration and development information and to interactively search and display this information through a GIS layering format. GIS data layers used on this website were generated by completion of tasks outlined in this contract and include the following 27 producing horizons: The Pennsylvanian Carbondale, Robinson, Casey, and Biehl horizons, The Mississippian Degonia, Clore, Palestine, Waltersburg, Tar Springs, Hardinsburg, Cypress, Bethel, Benoist, Renault, Aux Vases, Ste. Genevieve, St. Louis, Salem, Ullin and Carper horizons, The Devonian Lingle and Geneva horizons, The Silurian Niagaran reef and St. Clair horizons, The Ordovician Trenton and St. Peter horizons, and the Cambrian Mt. Simon horizon, a layer for gas storage wells. Other interactive layers include: oil wells, oil fields, townships, sections, municipalities, US highways, State highways, Interstate highways, counties, USGS 7.5 Minute Quadrangles and Digital Orthophotographic Quadrangle Map overlays. Additional layers and linked data include contoured structure maps, waterflood coverage and waterflood injection and production data, core analysis data and play portfolio data.

ArcIMS\#4.0 software was an essential component for distributing GIS data and applications on the website. This software (on the server side) works with client- side Web browsers to distribute mapping data through the World Wide Web (WWW). Connecting to the IMS website is easy and only requires an Internet Web browser (Internet Explorer 5.0 or Netscape 6.0) and typing the following URL into the address window: http://meltwater.isgs.uiuc.edu/website/iloil arcmap/viewer.htm.

Transfer of this technology has taken place at PTTC sponsored workshops conducted during February of 2003 and January of 2004 at the Illinois Oil and Gas Association Center in Mt Vernon, Illinois and at a combined PTTC/ISGS presentation at the Illinois Oil and Gas Association Annual Meeting March 5-6, 2004 in Evansville, Indiana. Demonstrations on data distributed through the website and instruction on how to access and use the map layers on the website were given at each presentation. Numerous other presentations and publications have highlighted the website and particular attributes of the website data and display.

Manipulation of layers available on the website permits users to customize maps for development and exploration purposes. Color-coded maps of all producing formations or selected producing horizons can be created by turning pertinent layers on or off. Tools in the menu bar are easily manipulated to produce custom maps which can be printed on a printer connected to a user's computer. Map titles and labels can be added to maps prior to printing, adding to the ability to create customized products from the website. Maps can be printed at any scale. Map details such as township and section lines and well spot locations become visible as map magnification increases. Features are displayed as the scale becomes appropriate for added detail.

Additional layers have been entered into a digital format including waterflood unit maps with injection and production data for approximately 1,700 waterflood areas or 
units in Illinois. An Access ${ }^{\circledR}$ database consisting of entries for over 168,000 core analyses has been completed. Maps of formations and wells in the core analysis database have been compiled. Over 90,000 formation depths have been verified and added to the ISGS Oracle database. These data were used to construct digital contour structure maps for the Barlow Limestone, the Ste. Genevieve Limestone and the New Albany Shale and added as layers to the ILoil ArcIMS website. Hand drawn color-coded producing formation maps created by Richard Howard and updated through 1985 have been scanned and made available on CD.

User feedback about the website has been very positive. They find the website to be very helpful to their work in petroleum exploration and development in Illinois. Individuals have reported that the website makes it easy to survey areas for "potential interest" and that the capability to overlay well data on other layers is "extremely valuable. Statements referring to the website such as "I don't know how I could continue to work in Illinois without it" are becoming common Company geologists are using the website to check the accuracy and completeness of their in-house well databases and to illustrate complex, multi-pay production characteristics of prospects for inclusion in prospect reports. One individual uses the site to delineate intricate stratigraphic trends that successfully identifies new prospects. A new oil discovery on one of these prospects is attributed to the use of the lloil website and verifies the success of this prospecting technique

\section{Experimental}

A new interactive map website was activated in February 2003 and can be accessed at http://meltwater.isgs.uiuc.edu/website/iloil arcmap/viewer.htm. This website was designed to enable the public and industry representatives to have access via their web browsers to interactively search and display GIS map layers pertinent to identifying underdeveloped areas (UDAs) in existing oil fields in Illinois. These maps are scalable and can be customized for individual petroleum exploration and development purposes. The current website was implemented with ESRI software and utilizes the ArcIMS\#4.0 and ArcSDE applications to query and display data residing in the Illinois State Geological Survey's basic well data file which resides in a relational Oracle ${ }^{\circledR}$ database.

The ILoil interactive website broke new ground in the interactive mapping capabilities at the ISGS. The project was the first to utilize an ArcGIS .mxd map file (a map view file created using ArcMap) and it was supported by the ArcMapServer software. The need to incorporate this evolving new technology was identified up-front and driven by the ILoil project. This technical strategy allowed an unlimited array of cartographic symbols to be used on the interactive map, which was far superior to the limited selection of four symbols available with the former method. The new method enabled oil and gas wells to be displayed with an expansive set of industry-defined data symbols. This strategy also provided project developers with unlimited access to ISGS data housed in the ArcSDE database, removing file limitations on the use of base data imagery like Digital Orthophoto quarter Quadrangle (DOQ) data and Digital Raster Graphic (DRG) files. This enabled us to offer DOQ and DRG layer options on the ILoil website. 


\section{Results and Discussion of Project}

This results and discussion section summarizes the progress on the tasks and deliverables outlined in the contract. Some of this material is best shown in its graphic or display presentation format.

Task 1. New Evaluation Tools for Identifying UDAs Task for Identifying UDAs: Computerized color-coded pay maps

The following tasks, designed to computerize and display oil production from individual horizons using the ISGS Oil and Gas Development Maps Series (a series of separate maps that covers the entire oil producing region in Illinois), have been completed. 1) A series of color coded pay maps have been completed and are available on the new website at http://meltwater.isgs.uiuc.edu/website/iloil arcmap/viewer.htm. 2) The integration and computerization of the databases required to generate the colored coded pay maps have been completed. 3) Digital production of the series of Oil and Gas Development Maps for Illinois has been completed. Updated plots of these maps are now available. 4) Computerization of maps using a GIS format has been completed. This format facilitates the separation and layering of each pay zone. These maps can now be used to identify individual pay zone trends and identify potential UDAs.

The subtasks completed in order to generate the color-coded pay map series are outlined as follows: 1) editing and updating producing formation data (approximately 83,000 wells) (completed), 2) formatting and translating producing formation data into GIS system (completed), 3) designing color-coded pay maps with GIS software (electronic copies) (completed), 4) serving maps on Internet in searchable and scalable format (completed).

An overview of the new website is outlined in the following 16 figures showing illustrations captured from the lloil website. The overview includes:1) An example of the introduction to the website that is being presented to the public (figures 1 through 3 ), 2) An introduction to evaluation techniques for identifying under-developed areas in Illinois (figures 4 through 6), 3) Instructions on using the tool bar for manipulating and scaling map data and layers, essential for identifying under-developed areas (figures 7 through 12), 4) Examples of the interactive display format using DOQ images and topographic images that have a multitude of uses for exploration and development (figures 13 through 16).

\section{About ILoil GIS Interactive Maps}

The current ILoil Interactive Map application was implemented in February 2003 with ESRI ArcIMS\#4.0, ArcSDE and Oracle database applications. The purpose of ILoil is to enable public access via their Web browser to interactively search and display various GIS layers. GIS data layers used on this website are generated by ISGS for DOE Contract No. DE-FC26-02NT15132. 
ArcIMS\#4.0 software is the foundation for distributing GIS data and applications on the Internet. This software (on the server side) works with your (client side) Web browser to distribute mapping data through the World Wide Web (WWW).

Connecting to the IMS is easy. Using an Internet Web browser (Internet Explorer 5.0) type the following URL into the address window:

http://meltwater.isgs.uiuc.edu/website/iloil arcmap/viewer.htm

\section{Illinois State Geolonical Survey \\ A GIS Approach for Play Portfolios to I mprove Oil Production in the Illinois Basin}

Oil and gas have been commercially produced in Illinois for over 100 years. Existing commercial production is from more than 52 named pay horizons in Paleozoic rocks ranging in age from the middle Ordovician to Pennsylvanian. Over 3.2 billion barrels of oil have been produced. Recent calculations indicate that remaining mobile resources in the Illinois Basin may be as much as 4.1 billion barrels. Thus, large quantities of oil, potentially recoverable using current technology, remain in Illinois oil fields despite a century of development. Opportunities for increased production may have been missed due to complex development histories, multiple stacked pays, and commingled production. These factors make thorough exploitation of pays and the application of secondary or enhanced recovery strategies difficult. Access to data, and the techniques required to evaluate and manage large amounts of diverse data, are major barriers to increased production of critical reserves in the Illinois Basin.

The Illinois Oil and Gas (ILoil) project was designed to alleviate data access constraints by developing new techniques for evaluation and identification of underdeveloped areas (UDAs) in and around petroleum reservoirs in Illinois. The Illinois State Geological Survey (ISGS) statewide oil and gas Oracle database was used to develop a series of oil and gas base maps with well location symbols that are color-coded by producing horizon. These maps can be presented either as a single pay horizon or layered to show multiple producing horizons.

A second series of pay horizon maps that identify underdeveloped areas have been generated from a statewide waterflood database. Pay analysis maps that identify reservoir quality and specific pay characteristics have also been developed from a statewide core analyses database. In combination, these underdeveloped pay area identification tools constitute a powerful analytical technology that incorporates all pays within the State of Illinois.

- $\quad$ UDA Evaluation Techniques

- $\quad$ ILOIL Interactive Map

The ILoil map service was developed by the Illinois State Geological Survey and funded by United States Department of Energy (DOE) contract DE-FC26-02NT15132 through the National Energy Technology Laboratory (NETL). Visitors can query and display well database attributes and create custom map views for printing. Kentucky and the Appalachian Region also have oil and gas resources Web mapping projects.

Contact Steve Gustison or Beverly Seyler for more information, or to send comments, about the ILoil project web resources. 
Return to the Oil and Gas main page

Updated: $11 / 10 / 2003 \underline{\text { SKB }}$

Figure 1. Introductory page for ILoil ArclMS website 
IIlinois State Geolopical Survey

Evaluation Techniques for I dentifying Under-Developed Areas (UDAs)

An approach combining the strengths of GIS software, spatial analysis, waterflood analysis, and petrophysical analysis is being used to group reservoirs within representative formations in the Illinois Basin into play portfolios. The digitization and integration of several data sources maintained at the ISGS have resulted in the development of new evaluation techniques for the identification of pay zone trends and potential UDAs. These techniques have generated new maps and data models.

Color-Coded Pay Maps

The ISGS produces a series of Oil and Gas Development Maps showing current well status, derived from information contained in basic well data files stored in the Oracle database. The basic well data files contain information for over 180,000 wells in Illinois and include fields for location, status, operator, formation tops, and API identification number. The Development Map series covers the entire oil producing region of Illinois. Producing formation data for approximately 83,000 wells have been updated and integrated with the well data files. The producing formation data can now be displayed on the Oil and Gas Development Maps, resulting in a series of color-coded pay maps. An obvious application of this technology is the capability it creates to visually recognize reservoir trends and geometries within individual formations and the potential of projecting these characteristics into under- and undeveloped areas for possible development. Digitizing these maps has enabled faster data updates and greater analytical flexibility by permitting separation and layering of each pay zone. Digitzing also has increased the array of data delivery options.

Historic Injection Wells

A basic well data file contains a substantial amount of information relevant to the exploration and development of reservoirs in the Illinois Basin. Records that identify historical injection wells no longer classified as such on Oil and Gas Development Maps, because their status has changed, are useful in the identification of UDAs. Mapping all injection wells, historic and current, on a single base identifies possible underdeveloped and resource-depleted areas.

Waterflood Records

The ISGS has collected data regarding injected and produced fluids from over 2,000 waterflood units in Illinois. Waterflood boundaries delineating acreage of the waterflood projects and fluid volumetric data are often available. Volumetric analysis using these data can be used to determine the efficiency and extent to which reservoir compartments have been drained. Therefore, this is a technique for evaluating potential UDAs. These types of analyses are commonly used to compare similar reservoirs to determine possible future reservoir performance and economic potential.

Flow Units

Grouping reservoirs with similar petrophysical characteristics is accomplished by extracting and analyzing porosity and permeability data from the ISGS core analysis database, which contains about 30,000 wells. Permeability and porosity cross-plots for core-defined flow units in the Aux Vases Sandstone, Cypress Sandstone, and Ste. Genevieve Limestone are used to establish unique petrophysical flow units for each of these formations. Identifying flow units and mapping their locations and thicknesses will aid in the grouping of reservoirs that exhibit similar characteristics into play portfolios.

Return to the Oil and Gas main page

Updated: 11/10/2003 $\underline{\text { SKB }}$

Figure 2. Webpage describing layers and databases that can be accessed and manipulated on the lloil ArcIMS website. 
General Instructions for the website show browser requirements for using the interactive map site. Instructions for operating the website are included.

\section{General Instructions}

\section{Illinois State Geolonical Survey \\ I Ilinois Oil and Gas Resources (I Loil) I nternet Map Service}

The Illinois Oil and Gas Resources Web mapping project enables on-line access to the large petroleum database of over 180,000 Illinois well records. This database has been in development for many years by the Oil and Gas Section of the Illinois State Geological Survey. Traditionally, these well records have only been available during regular business hours at the Geological Records Unit in Champaign, Illinois.

\section{Notes for Interactive Mapping}

Your browser must have Frames and JavaScript enabled.

The Web interface is best viewed using Internet Explorer.

It is not possible to bookmark map views. Instead, bookmark this access page.

Instructions for accessing Illinois Oil and Gas well data, a screen shot of the Interactive Mapping Web Interface, and descriptions of the navigational tools of the Interactive Mapping Web Interface are detailed below. Read the Illinois DNR digital data License Agreement before you proceed.

\section{Open the ILOIL Interactive Mapping Web I nterface}

\section{Instructions for Accessing I llinois Oil and Gas Resources Data}

Map manipulation tools are offered on the left side of the interface. The currently selected tool will be outlined in red, as the "Zoom In" tool is outlined in the screen shot shown below. Data layer visibility and activation control is located on the right side of the interface. The visitor must set desired "Active" layer combinations and then implement "Refresh Map" in order to create a custom map view.

\section{Step 1: Enlarge an appropriate area.}

The "Zoom In" tool is the default tool upon launch of the Interactive Mapping Interface.

Step 2: Set to "Visible" any data layers you wish to enable.

Data layers are listed in order by geologic time period. By default, the "Oil Fields" data layer is set to "Visible." Any combination of data layers can be set to "Visible."

Step 3: Click the "Refresh Map" button.

The "Refresh Map" button is listed below all data layers and will complete alterations to the selection of "Visible" layers. Data layers "Wells", "Counties", and "Oil Fields Data" are set to "Visible" in the screen shot shown below.

\section{Step 4: Access Data}

To use the "Select Multiple" rectangle tool, first set the "Active" layer to the desired data layer by clicking the corresponding radio button. The "Wells" data layer is set as "Active" in the screen shot shown below. 


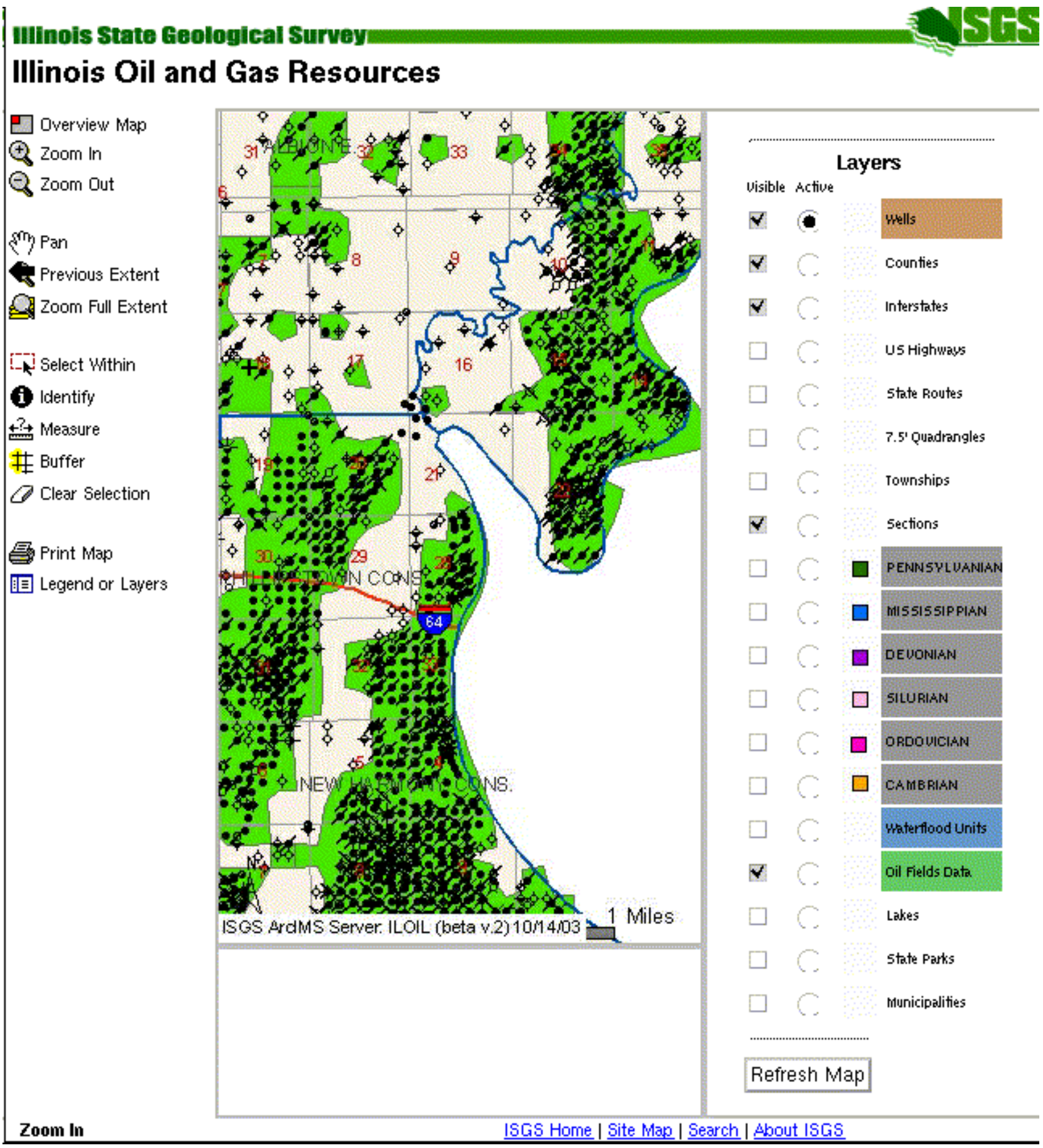

\begin{tabular}{|l|l|l||}
\hline \multicolumn{2}{|c|}{ Navigational Tools of the I LOI L I nteractive Mapping Web I nterface } \\
\hline \begin{tabular}{l|l|l|}
\hline Overview \\
Map
\end{tabular} & Turn the Overview Map displayed in the upper left corner of the map frame on or off. \\
\hline $\mathbf{9}$ & Zoom In & $\begin{array}{l}\text { Enlarge the map image by clicking on a spot or dragging a rectangle around the area of } \\
\text { interest. }\end{array}$ \\
\hline $\mathbf{Q}$ & Zoom Out & $\begin{array}{l}\text { Reduce the map image by clicking on a spot or dragging a rectangle around the area of } \\
\text { interest. }\end{array}$ \\
\hline
\end{tabular}




\begin{tabular}{|c|c|c|}
\hline (nin) & $\begin{array}{l}\text { Pan Map } \\
\text { View }\end{array}$ & Drag the map image so that the area of interest is shifted within the view. \\
\hline Q & $\begin{array}{l}\text { Previous } \\
\text { Extent }\end{array}$ & Return the map view to the previous zoom level and location. \\
\hline 요 & $\begin{array}{l}\text { Zoom to } \\
\text { Full Extent }\end{array}$ & $\begin{array}{l}\text { Zoom the map view out to the the fullest extent of all data layers, in this case, the } \\
\text { boundary of the state of Illinois. }\end{array}$ \\
\hline-1 & $\begin{array}{l}\text { Select } \\
\text { Within }\end{array}$ & $\begin{array}{l}\text { Graphically select multiple records by dragging a rectangle around the area of interest. } \\
\text { Features in the rectangle will be selected and highlighted in light blue. A table of } \\
\text { information pertaining to the active layer will appear. } \\
\text { The user MUST specify the "active layer" to the desired data layer county. }\end{array}$ \\
\hline (9) & Identify & $\begin{array}{l}\text { Identify a selected feature. A table of information for the selective feature and within the } \\
\text { active layer will appear. }\end{array}$ \\
\hline 2 & Measure & $\begin{array}{l}\text { Click on the map to create line segments. Distance (in miles) for each line segment and } \\
\text { the total of all segments will be displayed. }\end{array}$ \\
\hline \# & Buffer & $\begin{array}{l}\text { First, use the "Select Within" tool to select multiple records. Features in the rectangle will } \\
\text { be selected and highlighted in light blue. Use the "Buffer" dialog box to highlight features } \\
\text { from a specified data layer within a specified distance (in miles). }\end{array}$ \\
\hline$O$ & $\begin{array}{l}\text { Clear } \\
\text { Selection }\end{array}$ & Unselect all previously selected features. \\
\hline 量 & $\begin{array}{l}\text { Print Map } \\
\text { View }\end{array}$ & $\begin{array}{l}\text { The user is prompted to submit a map title. The user types and submits the title, a new } \\
\text { window opens that contains a formatted title, map image, and legend suitable for printing } \\
\text { Use the browser "Print" button to print the map. }\end{array}$ \\
\hline 国 & $\begin{array}{l}\text { Legend or } \\
\text { Layers }\end{array}$ & $\begin{array}{l}\text { Toggle between the layer list and the map legend. The layer list enables the user to set } \\
\text { the active data layer and also set the display of individual data layers to be on or off. The } \\
\text { legend is a graphical representation of the symbology of all visible map layers. }\end{array}$ \\
\hline
\end{tabular}

Return to the Oil and Gas main page

Updated: 11/ 10/2003 SKB

Figure 3. General instructions and tutorial for using tools to manipulate maps and layers in ILoil ArcIMS website. 


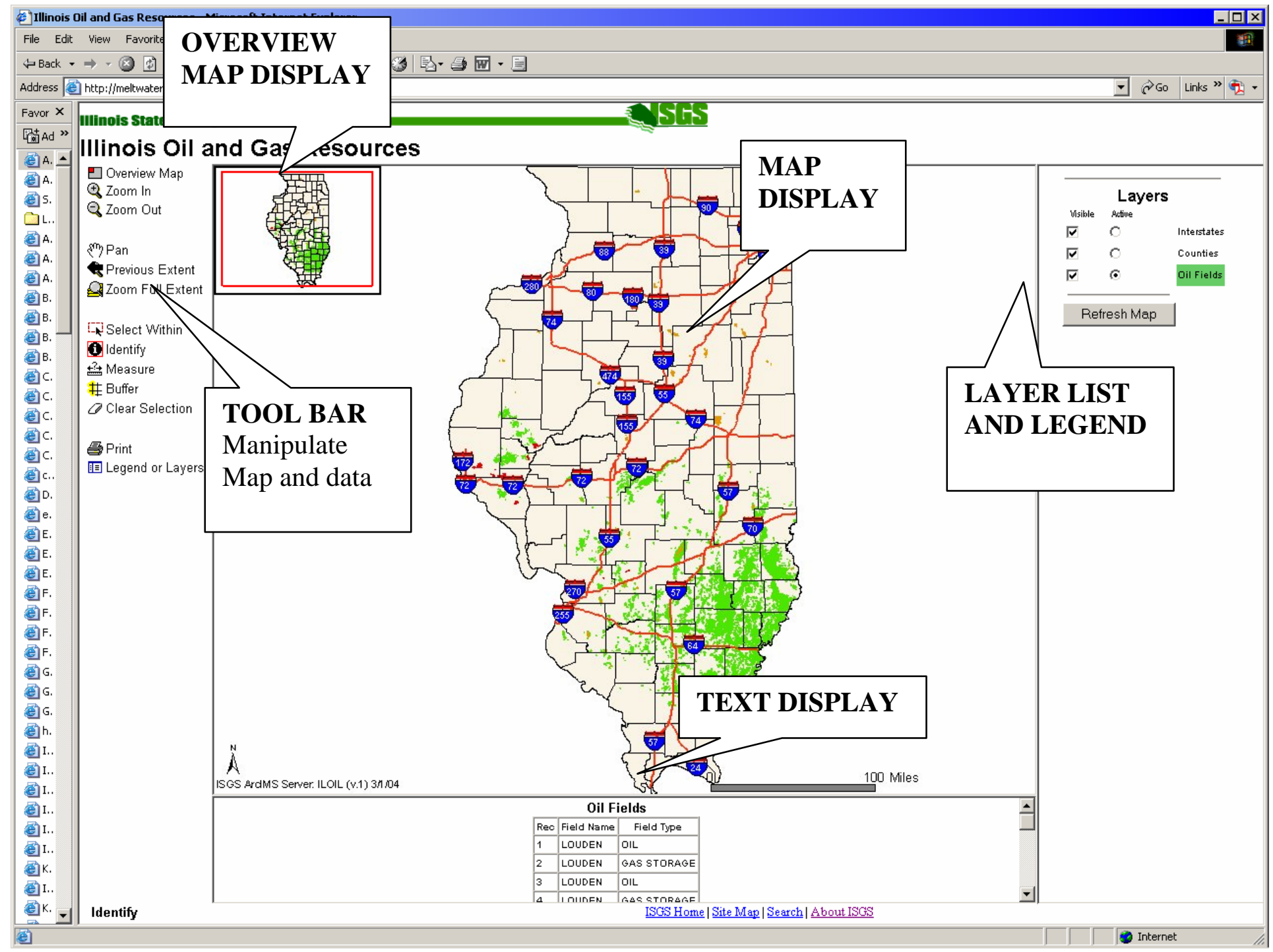

Figure 4. Example of the interactive display format designed for the front page of the ILoil ArcIMS website. 
The following is a list of the layers that can be displayed on the Website either separately or in combination.

\section{PENNSYLVANIAN PRODUCERS \\ Carbondale \\ Robinson \\ Casey \\ Biehl \\ MISSISSIPPIAN PRODUCERS \\ Degonia \\ Clore \\ Palestine \\ Waltersburg \\ Tar Springs \\ Hardinsburg \\ Cypress \\ Bethel \\ Benoist \\ Renault \\ Aux Vases \\ Ste. Genevieve \\ St. Louis \\ Salem \\ Ullin \\ Carper}

DEVONIAN PRODUCERS

Lingle

Geneva

SILURIAN PRODUCERS

Niagaran

St. Clair

ORDOVICIAN PRODUCERS

Trenton

St. Peter

CAMBRIAN PRODUCERS

Mt. Simon

Wells

Oil Fields

Townships

Sections

Municipalities

US Highways

State Routes

Interstates

Counties
7.5 Minute Quads

Oil \& Gas Development Overlay

Digital Orthophoto quarter Quadrangle (DOQ)

Waterflood Units

Lakes 


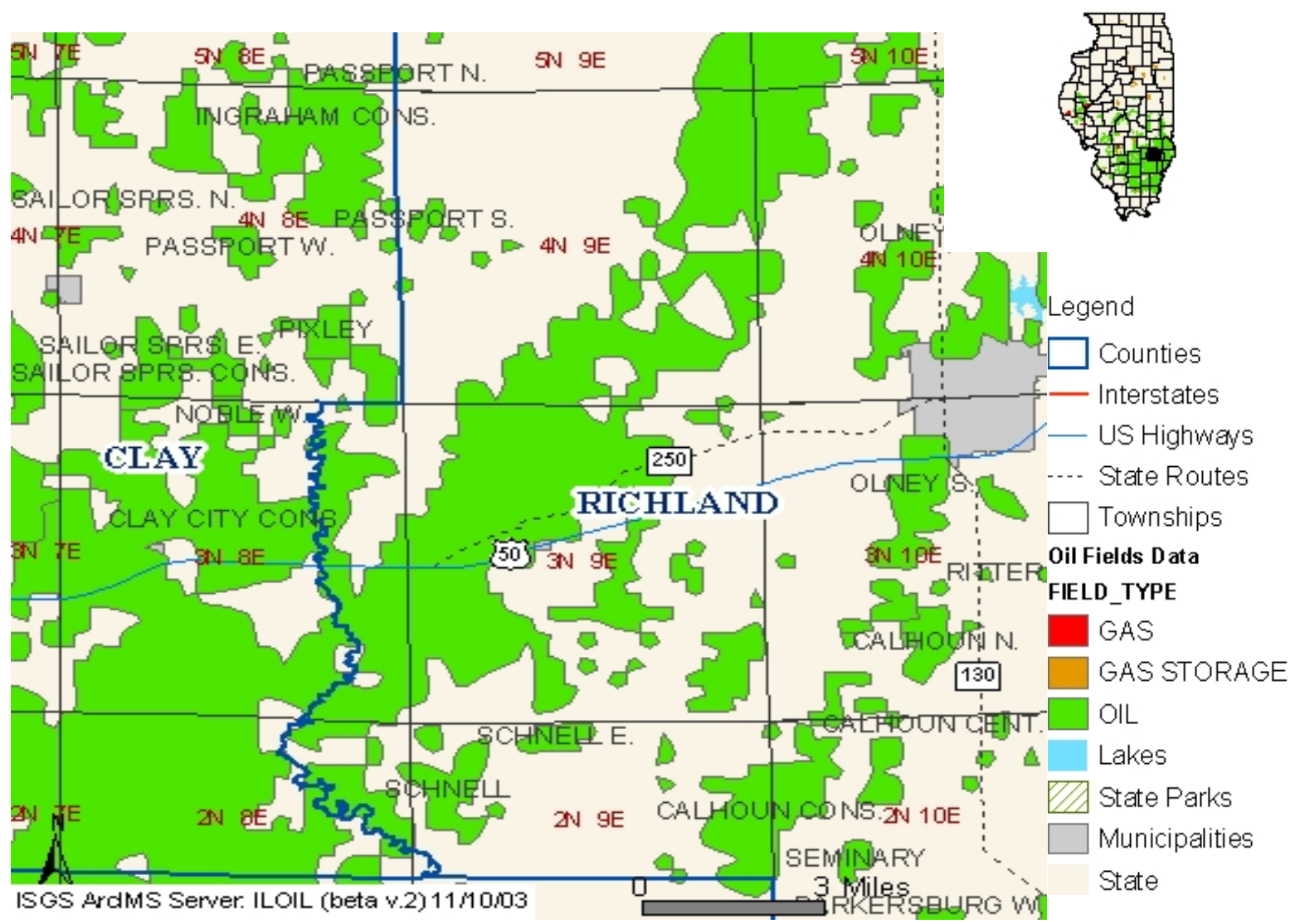

Figure 5. View using Zoom in tool for portions of Clay and Richland Counties.

\begin{tabular}{|c|c|c|c|c|c|c|c|c|c|c|c|c|}
\hline \multicolumn{13}{|c|}{ duction: 363365000 barrels to end of 1998) } \\
\hline $\operatorname{Rec}$ & Pay Zones & $\begin{array}{c}\text { Depth } \\
\text { (ft.) }\end{array}$ & $\begin{array}{c}\text { Discovery } \\
\text { Year }\end{array}$ & $\begin{array}{c}\text { Area } \\
\text { Proved } \\
\text { (acres) }\end{array}$ & $\begin{array}{c}\text { Wells } \\
\text { comp. to } \\
\text { prod. } \\
\text { year }\end{array}$ & $\begin{array}{l}\text { Wells } \\
\text { reptd. } \\
\text { prod. } \\
\text { year }\end{array}$ & $\begin{array}{l}\text { Wells } \\
\text { Abd. } \\
\text { prod. } \\
\text { year }\end{array}$ & $\begin{array}{l}\text { GR } \\
\text { API }\end{array}$ & $\begin{array}{c}\text { Sulf } \\
\text { ur } \\
(\%)\end{array}$ & $\begin{array}{l}\text { Rock } \\
\text { Type }\end{array}$ & $\begin{array}{c}\text { Pay } \\
\text { Thick } \\
\text { ness }\end{array}$ & $\begin{array}{c}\text { Struc } \\
\text { ture }\end{array}$ \\
\hline 1 & Waltersburg & 2175 & 1952 & 20 & 2 & 0 & 0 & 36 & & S & 6 & AL \\
\hline 2 & Tar Springs & 2560 & 1949 & 130 & 9 & 0 & 0 & 38 & & $\mathrm{~s}$ & 15 & AL \\
\hline 3 & Cypress & 2635 & 1937 & 9270 & 693 & 0 & 3 & 36 & & $\mathbf{S}$ & 15 & AL \\
\hline 4 & Bethel & 2800 & & 450 & 37 & 0 & 0 & 39 & & $\mathbf{S}$ & 15 & AL \\
\hline 5 & Aux Vases & 2940 & 1942 & 35570 & 2567 & 0 & 17 & 38 & & S & 15 & $\mathrm{AL}$ \\
\hline 6 & St Genevieve & 3003 & & & 2 & 2 & & & & & 3 & \\
\hline 7 & Ohara & 3020 & & 74160 & 349 & 0 & 4 & 38 & & OL & 5 & $A C$ \\
\hline 8 & St Louis & 3025 & 1949 & 4140 & 482 & 0 & 2 & 38 & & $\mathbf{L}$ & 3 & A \\
\hline 9 & Spar Mountain & 3030 & & & 791 & 0 & 5 & 38 & & LS & 8 & $A C$ \\
\hline 10 & McClosky & 3050 & 1937 & & 2774 & 1 & 17 & 39 & & OL & 10 & $A C$ \\
\hline 11 & Salem & 3590 & 1950 & 13140 & 1046 & 2 & 8 & 39 & & $\mathbf{L}$ & 10 & A \\
\hline 12 & Ullin & 3600 & 1952 & 710 & 82 & 0 & 1 & 40 & & $\mathbf{L}$ & 17 & A \\
\hline 13 & Carper & 3806 & 1979 & 80 & 5 & 0 & 0 & & & S & 6 & \\
\hline 14 & Devonian & 4350 & 1949 & 140 & 10 & 0 & 0 & 39 & & $\mathbf{L}$ & 10 & A \\
\hline
\end{tabular}

Figure 6. Field data table for Clay City Consolidated that can be accessed by activating field data and by using the identify tool. This data is from the annual report of the Petroleum Industry in Illinois. 
Figure 7. Screen capture close-up (Zoom In) of an area from the interactive statewide map. This display illustrates the individual color coded producing wells. Details such as township and section boundaries and well locations are shown as map area decreases (as Zoom In tool is used wells layer is activated). 

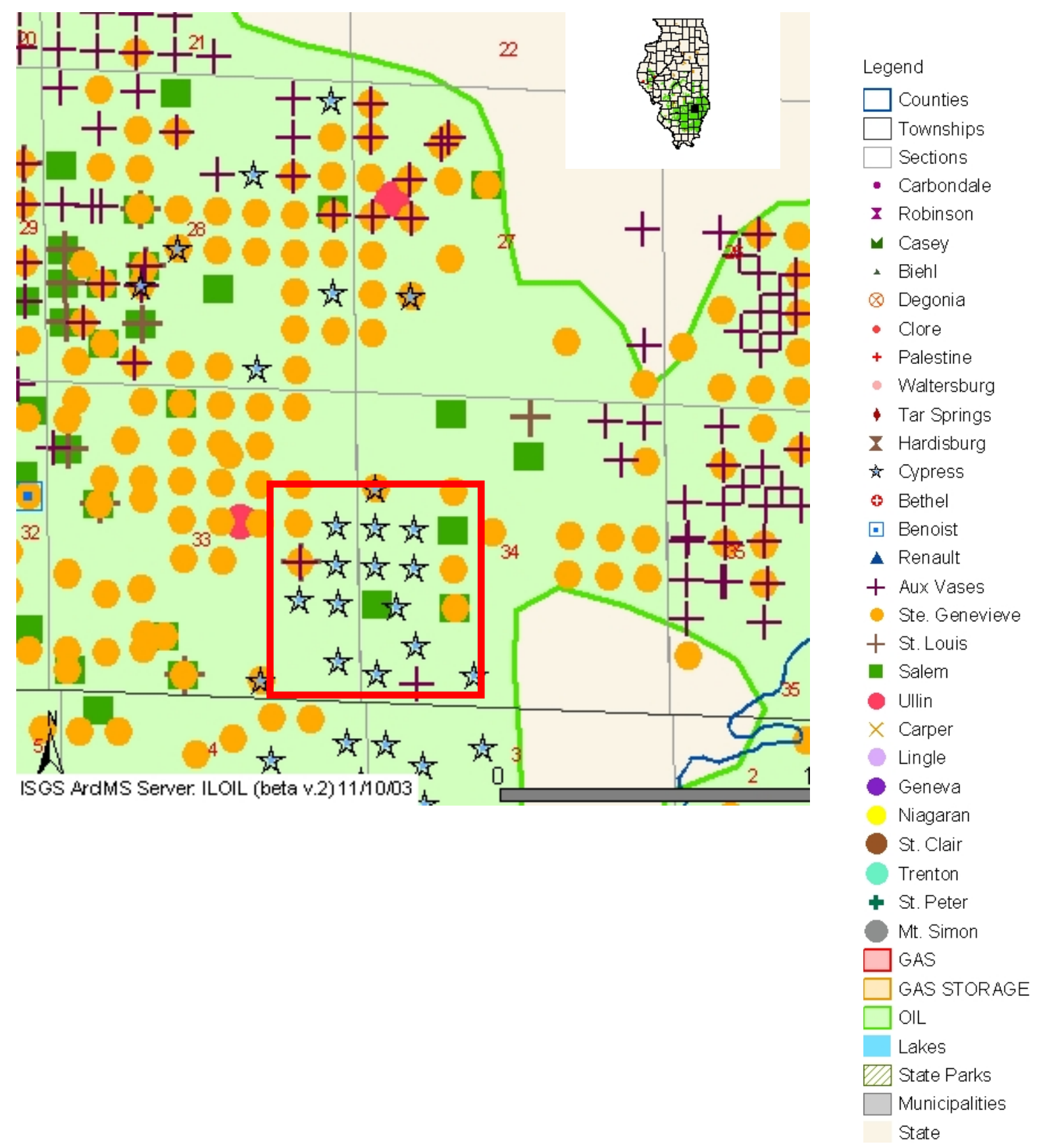

Figure 8. Additional detail and wells producing from multiple pay zones can be observed by using the zoom in tool. The select within tool can be used to draw a box (red box) around wells of interest. 


\begin{tabular}{|c|c|c|c|c|c|c|c|c|}
\hline $\operatorname{Rec}$ & API Number & Status & Company Name & $\begin{array}{l}\text { Farm } \\
\text { Name }\end{array}$ & $\begin{array}{c}\text { Farm } \\
\text { Number }\end{array}$ & Elevation & Comp. Date & $\begin{array}{l}\text { Total } \\
\text { Depth }\end{array}$ \\
\hline 1 & 120250149100 & OILP & Reynolds, Earl B. & Dehart & B-1 & 434 & \begin{tabular}{|l} 
Sun, 1 Nov \\
1959
\end{tabular} & 3005 \\
\hline$\underline{2}$ & 120250109900 & OILP & Reynolds, Earl B. & $\begin{array}{l}\text { Edems- } \\
\text { Moseley }\end{array}$ & 2 & & Sat, 1 Nov 1958 & 2623 \\
\hline$\underline{3}$ & 120250115200 & OILP & Reynolds, Earl B. & Dehart & 1 & 438 & \begin{tabular}{|l} 
Tue, 12 May \\
1959
\end{tabular} & 2612 \\
\hline$\underline{4}$ & 120250118900 & OILP & Reynolds, Earl B. & Schnautz L & 1 & 437 & Wed, 1 Jul 1959 & 3011 \\
\hline$\underline{5}$ & 120250118800 & OILP & Reynolds, Earl B. & Dehart & 2 & 0 & Wed, 1 Jul 1959 & 2615 \\
\hline$\underline{6}$ & 120250317000 & OILP & Partlow \& Cochonour & $\begin{array}{l}\text { Moseley A } \\
\text { den }\end{array}$ & 1 & 435 & $\begin{array}{l}\text { Thu, } 1 \text { Nov } \\
1951\end{array}$ & 3007 \\
\hline$\underline{7}$ & 120252519500 & OILGSP & Van Fossan Oil Corp. & DEHART & 1 & 438 & $\begin{array}{l}\text { Mon, } 30 \text { Dec } \\
1974\end{array}$ & 2992 \\
\hline 8 & 120252522700 & OILP & Booth Oil Co., Inc. & Dehart, L. & 1 & 438 & Fri, 17 Jan 1975 & 3564 \\
\hline$\underline{9}$ & 120252525700 & DAOP & Booth Oil Co., Inc. & DEHART & 2 & 437 & \begin{tabular}{|l} 
Fri, 23 May \\
1975
\end{tabular} & 2990 \\
\hline
\end{tabular}

Figure 9. Using the select within tool enables the user to retrieve individual well data from the ISGS Oracle database. This is a table of well data for wells within the red box in figure 8. 


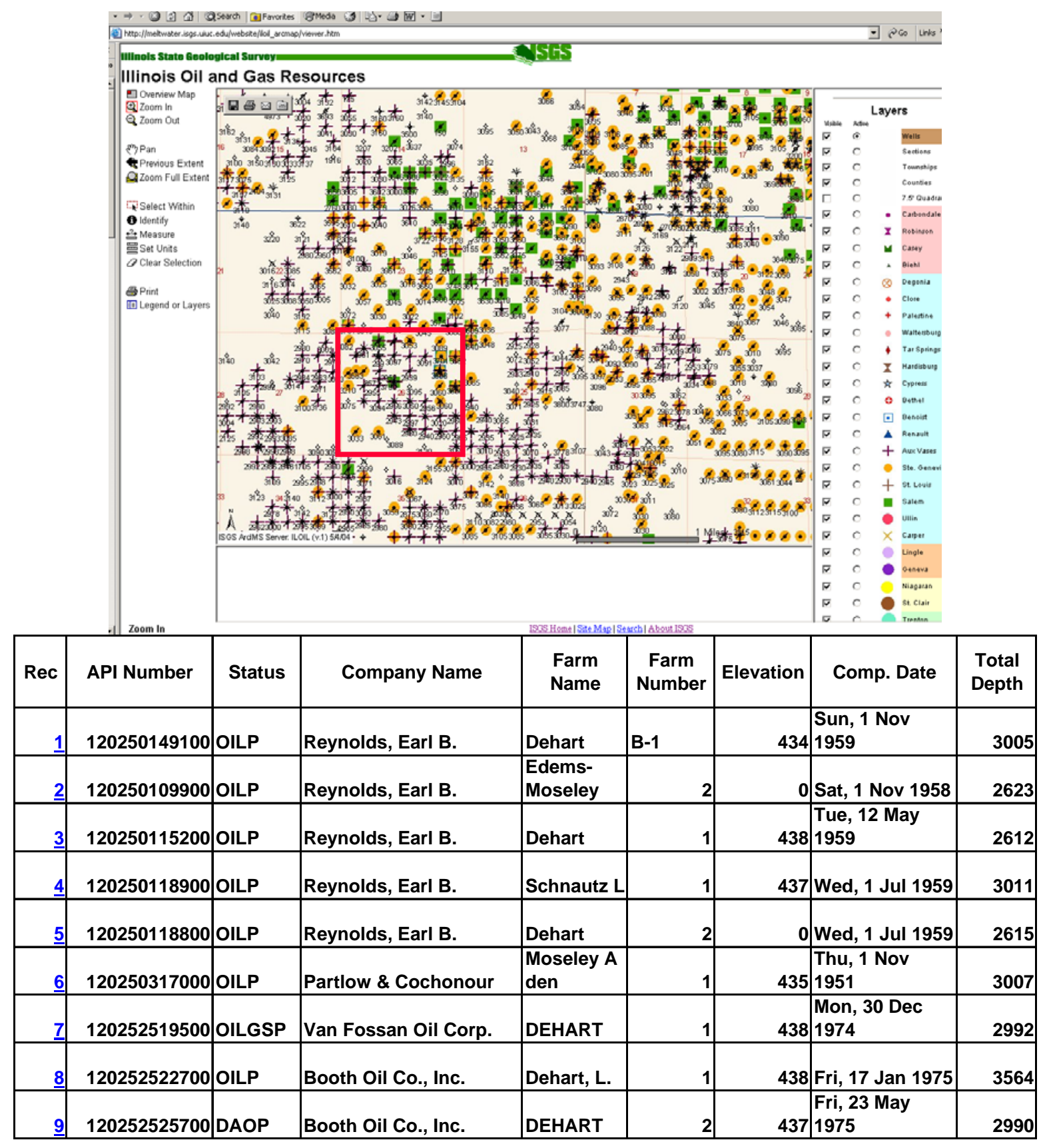




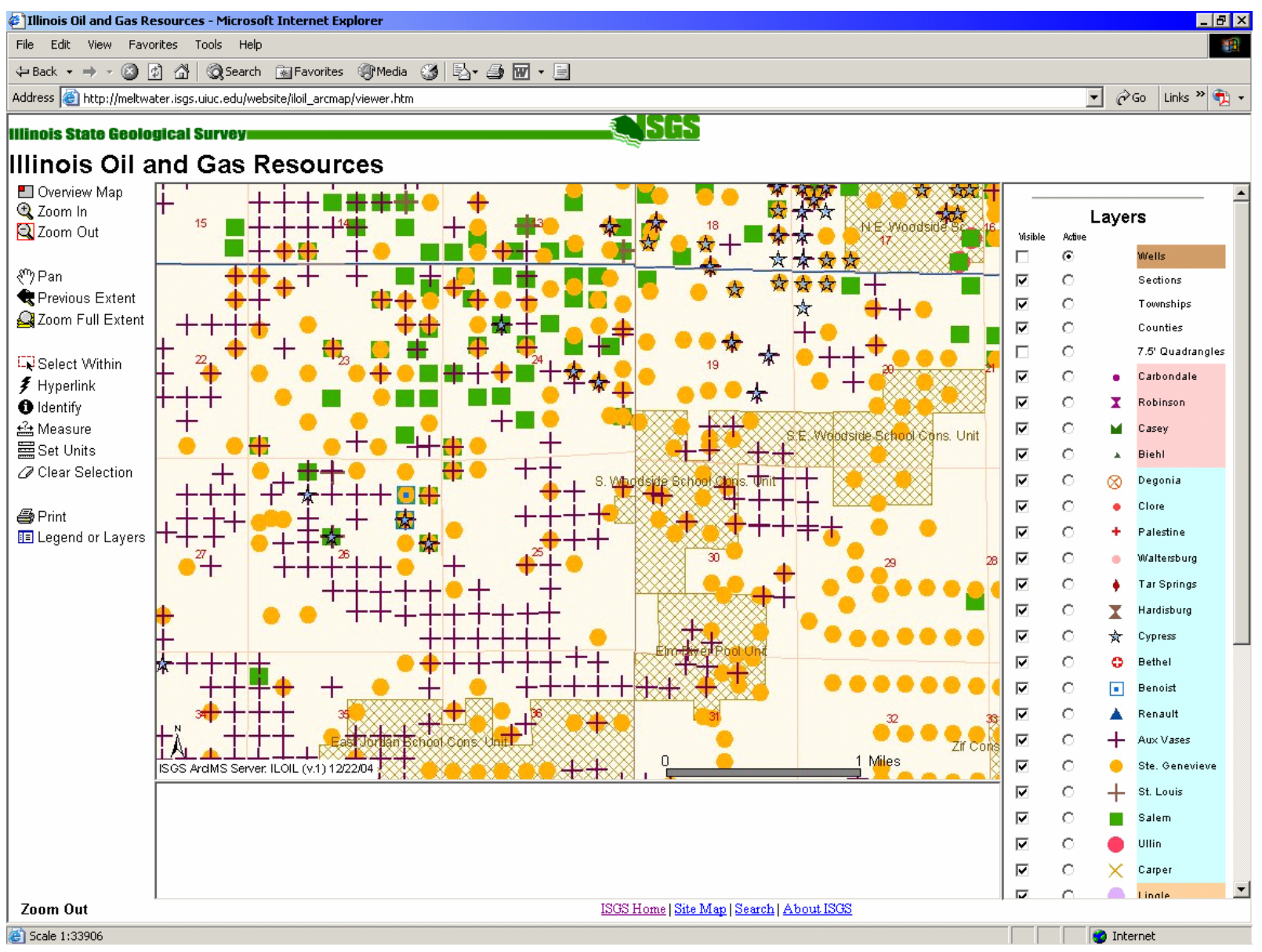

Figure 11. The ILoil ArcIMS layering technique can be used to declutter a map to show producing trends by formation. This can be done by deactivating the well layer and by checking which formations are desired on the map and then selecting the refresh map button. 


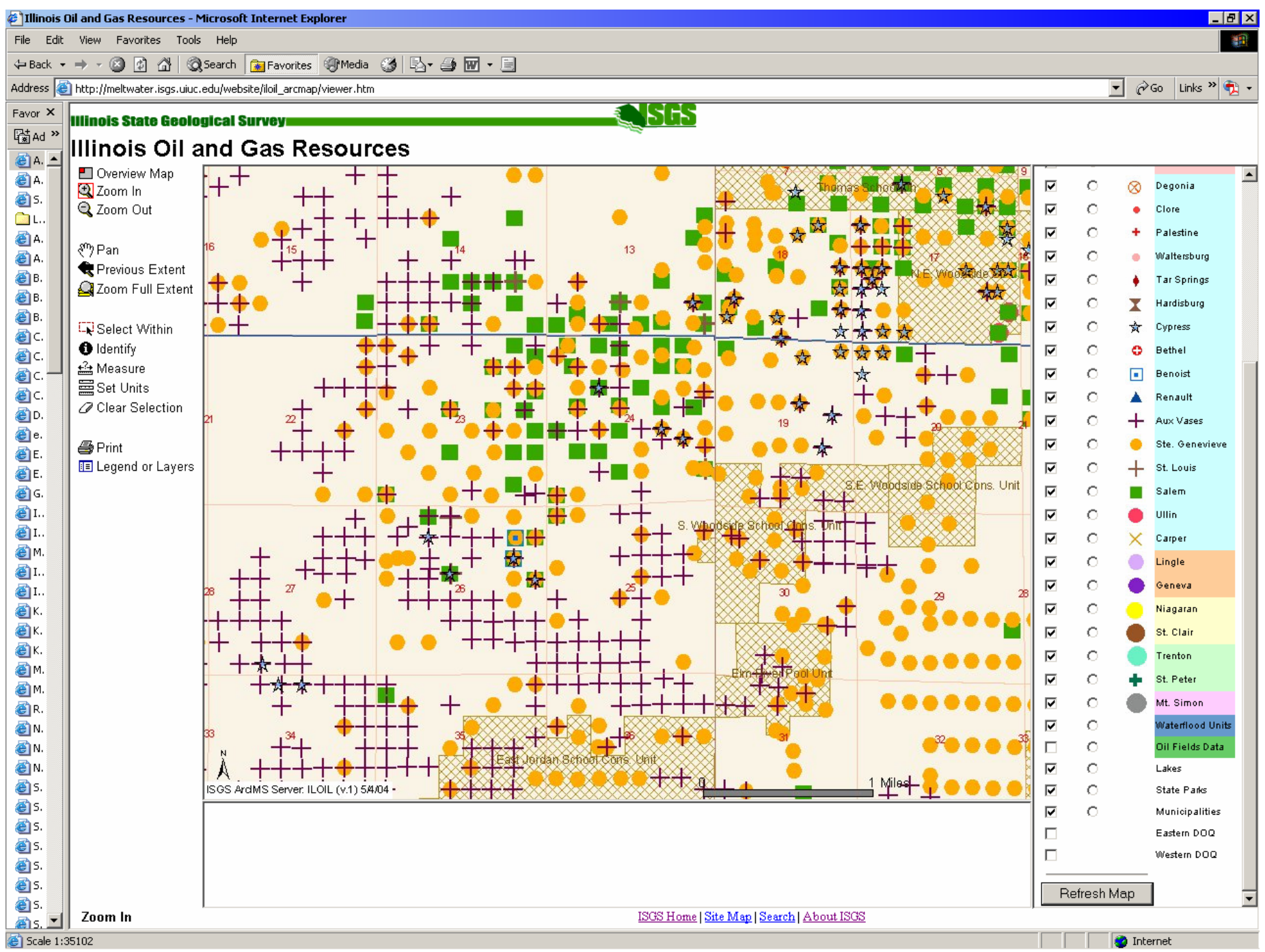

Figure 12. The website can be used to show reservoir patterns and geometries. This example shows Aux Vases reservoirs in purple crosses, Ste. Genevieve reservoirs in orange circles and Salem reservoirs in green squares over an area of approximately 20 square miles. Waterflooded areas are shown by hachure marks. 


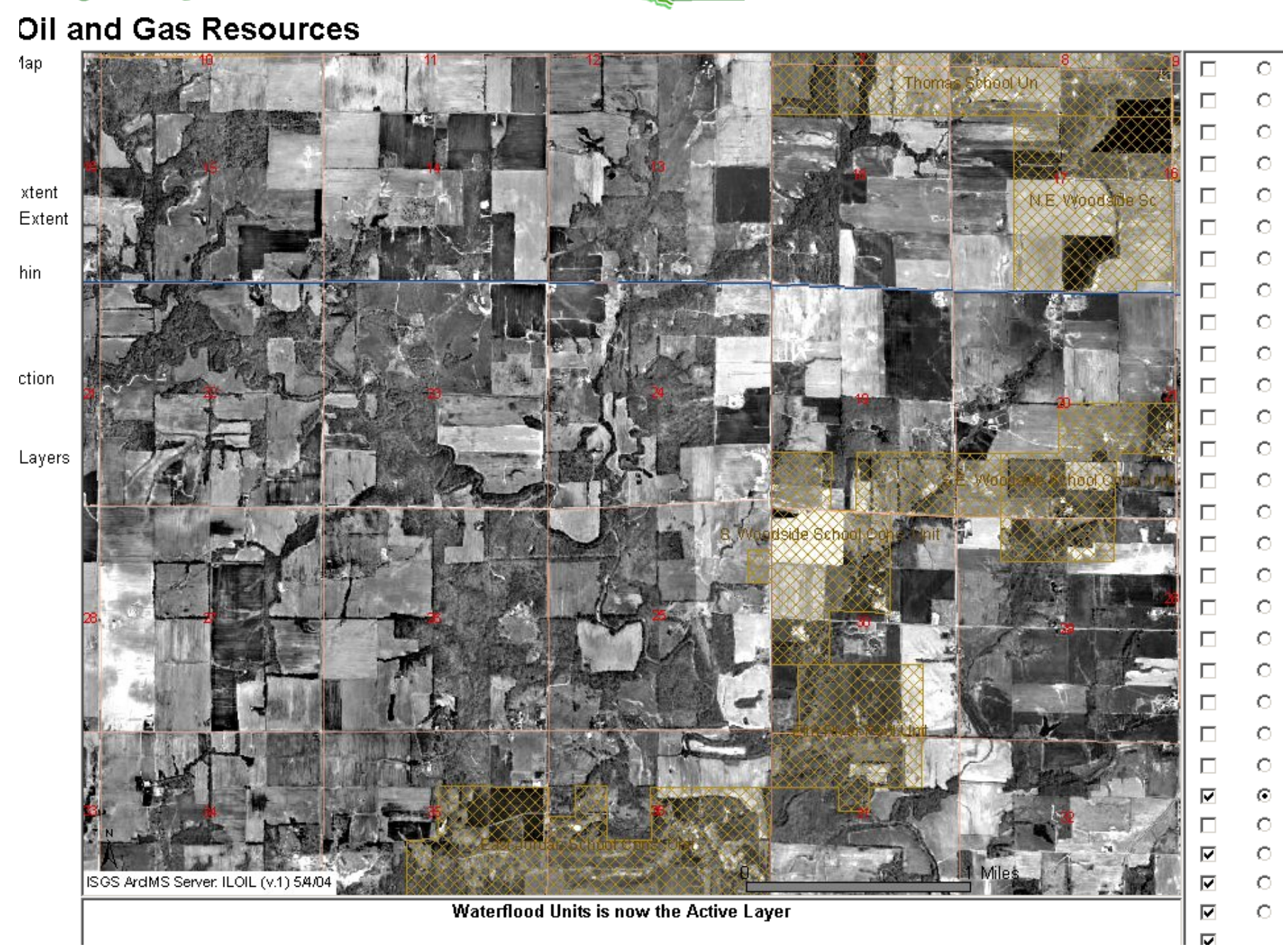

Figure 13. High Resolution Arial photographs DOQs are available for use as base maps. This layer shows many surface features. This map also shows waterflood units with hachure marks. Same area as shown in figure 12. 


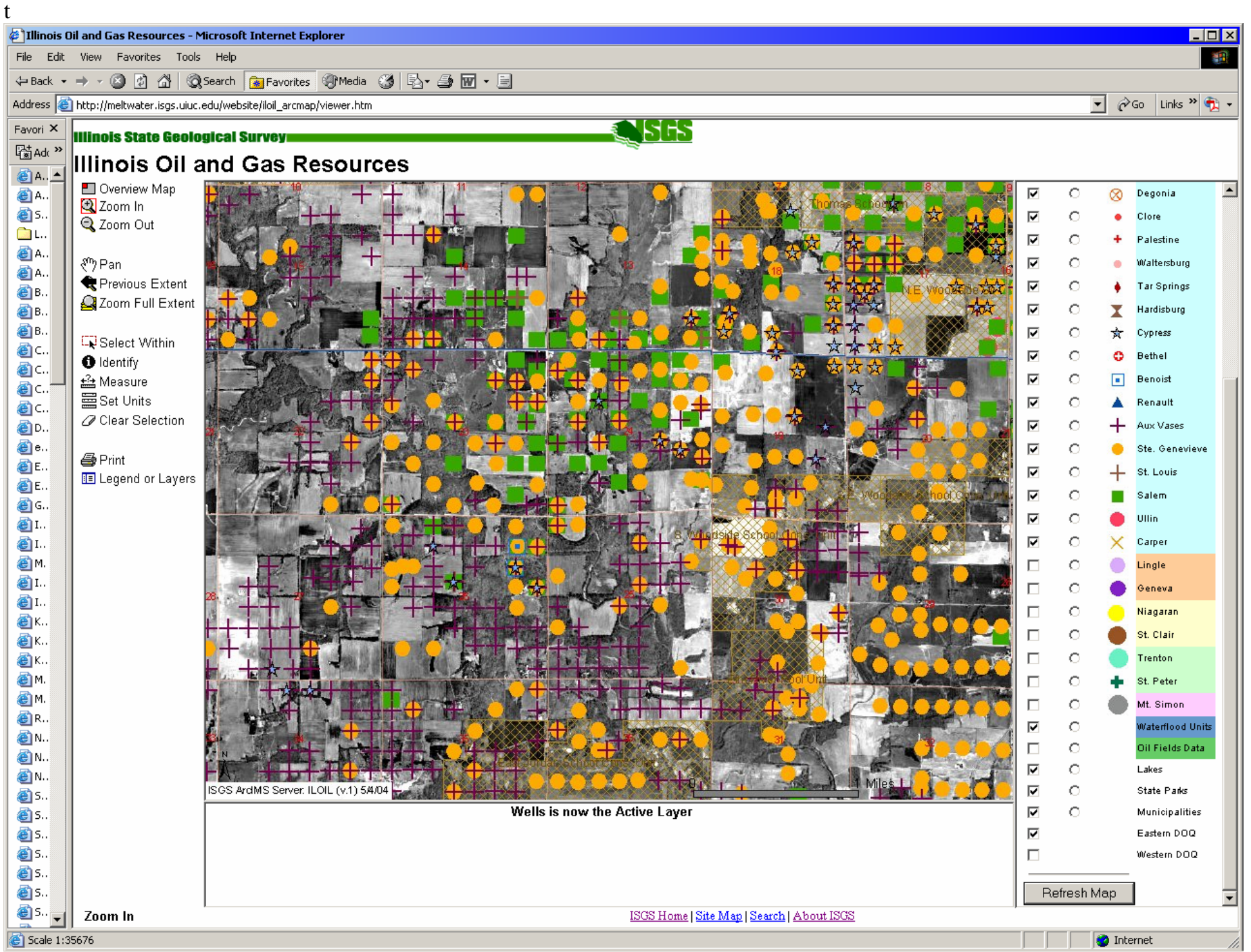

Figure 14. Color-coded producing horizon information on a DOQ base map. This map layer combination provides much information on surface features as well as producing formation information and can be used to plan oil development projects. Same area as shown in figures 11,12 and 13. 


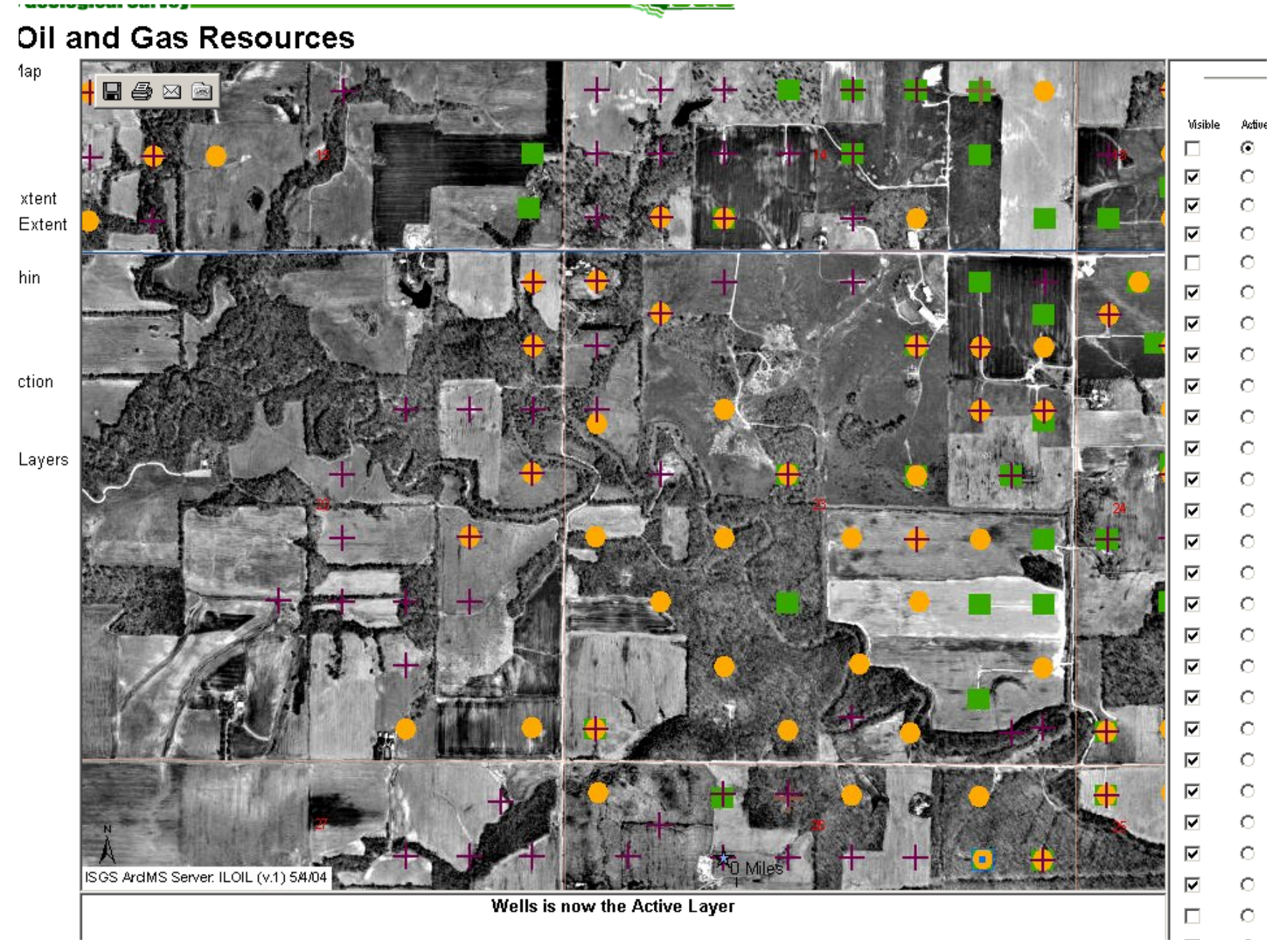

Figure 15. Close-up of previous map showing producing wells and color-coded producing horizons on a DOQ base map. The DOQ shows surface information such as roads, sream meanders and farm fields that is useful for planning oil field development. 


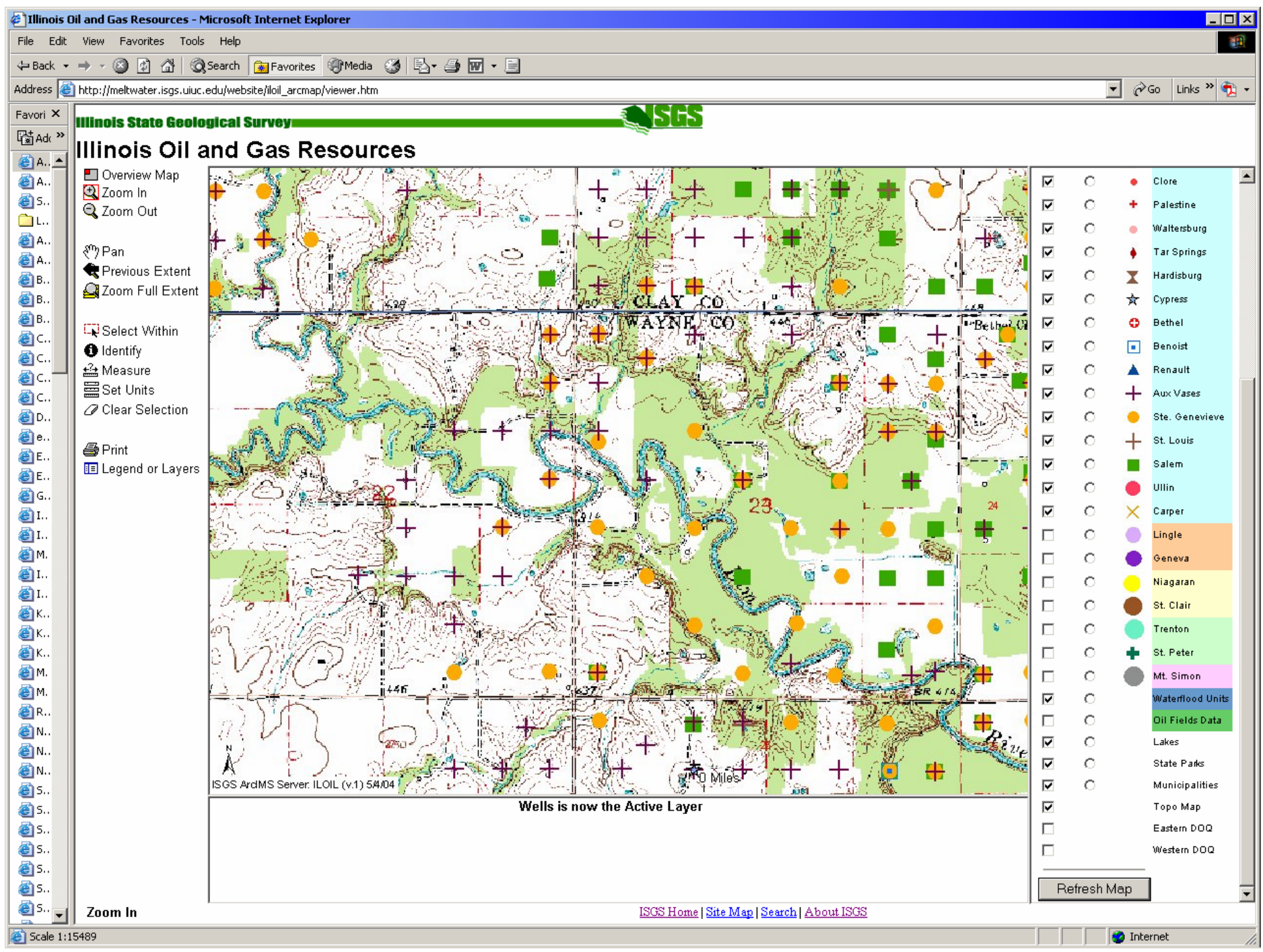

Figure 16. Same area as previous figure with USGS Quadrangle map as base map for wells that are color coded by producing horizon. Quadrangle maps also provide useful surface feature information such as elevation, relief, vegetation and land use.

Task 2. New Evaluation Technique for identifying UDAs: Automate Historic Injection Wells

The Basic Well Data File contains a substantial amount of data relevant to the exploration and development of reservoirs in the Illinois Basin. Among the data most useful in the identification of UDAs are records that identify historic injection wells that are no longer posted as injection wells on Oil and Gas Development Maps because their status has changed. Mapping of all injection wells (historic and current) on a base of the color-coded pay maps can be used to eliminate possible resource-depleted areas and add further utility and refinement to this new screening methodology. The completed subtasks associated with adding historical injection wells to the color-coded map series are outlined below: 1) extract from basic well datafile records, all current and historic injection wells 
2) generate maps of all injection wells with area of influence buffers and overlay onto colorcoded pay maps (all injection wells are shown on maps)

3) create new maps showing proven pay areas that have not been waterflooded nor influenced by waterflood activities

4) serve maps on)

Task 3. New Evaluation Technique for identifying UDAs: Computerization of waterflood records

The ISGS has collected data regarding injected and produced fluids from over 1,700 water flood units in Illinois, data from these waterflood units and waterflood areas has been entered into a digital database. A digital database of current waterflood units in Illinois has been incorporated into the digital Oil and Gas Development Map series. Waterflood units and waterflood areas are now displayed on Oil and Gas Development Maps. The ability to graphically display and visualize the combination of particular pay zones from the color-coded pay maps with injection well locations, coupled with waterflood volumetrics is now possible using the ArcIMS ILoil website. Completed subtasks are as follows:

1) input data from 1,700 historic waterflood reports; make waterflood record data available in digital format on the internet.

2) generate acreage maps for waterflood units by producing formation (digital waterflood unit maps for current waterflood units in Illinois are available

3) generate maps delineating acreage by formation with waterflood opportunities

4) serve maps on Internet 
compiled. Additional analytical and statistical analyzes to determine average porosity by formation was conducted using these data. This data was analyzed to identify highly porous and permeable zones as well as areas with lesser porosity and permeability .This information can be used to recognize areas with additional waterflood potential. Completed subtasks include:

1) Comprehensive core analysis database was compiled

2) Core analysis database added to the ISGS Enterprise Oracle database

2) created and edited maps showing wells with core analysis data

3) serve database on internet

4) extract porosity and permeability data from core analysis database by formation (Data has been compiled and extracted for the Cypress, Aux Vases and Ste. Genevieve Formations). 

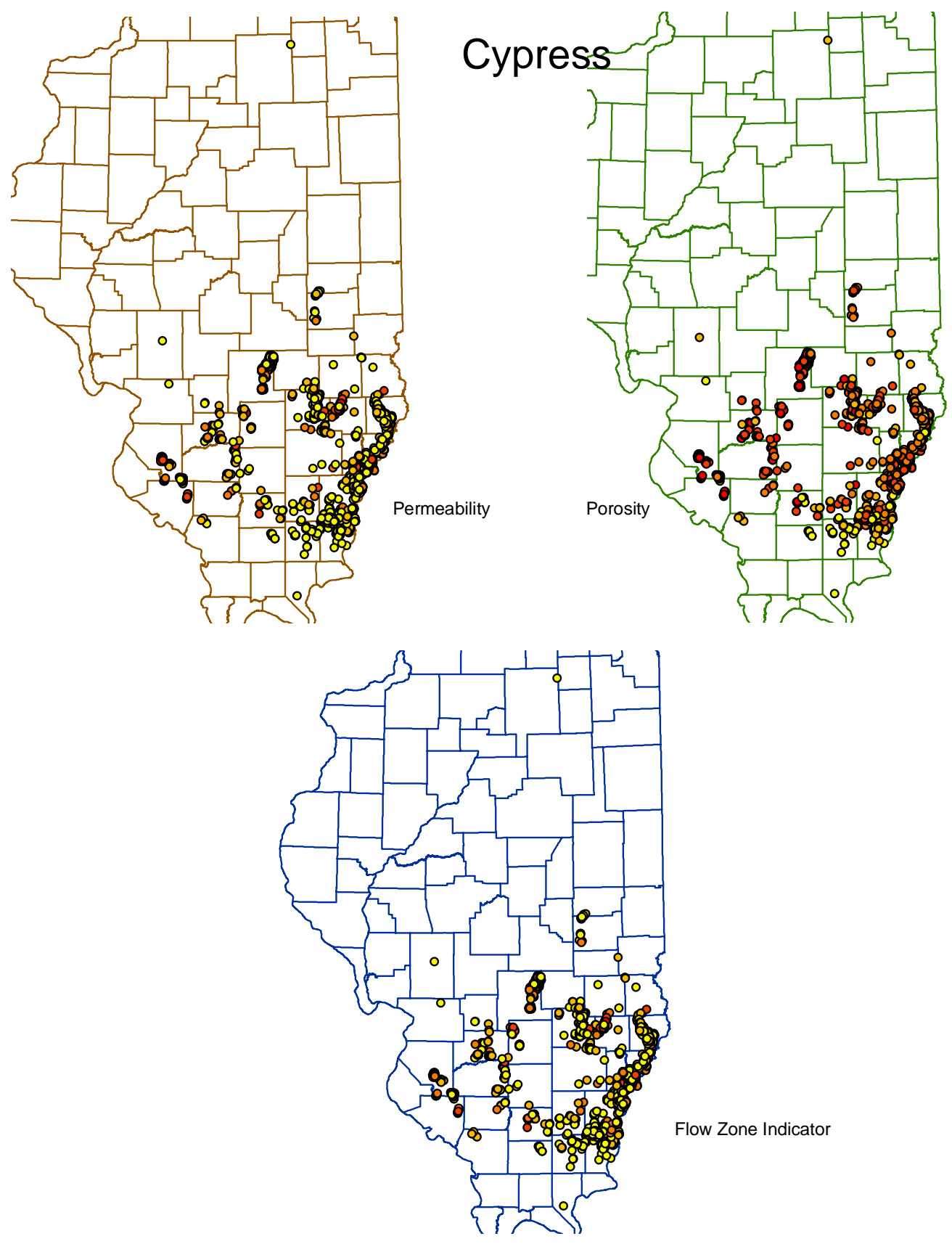

Figure 18. Wells with core analysis data for the Cypress Sandstone. Wells with high porosity and permeability are in red, medium values are shown in orange and low values are shown in yellow. 

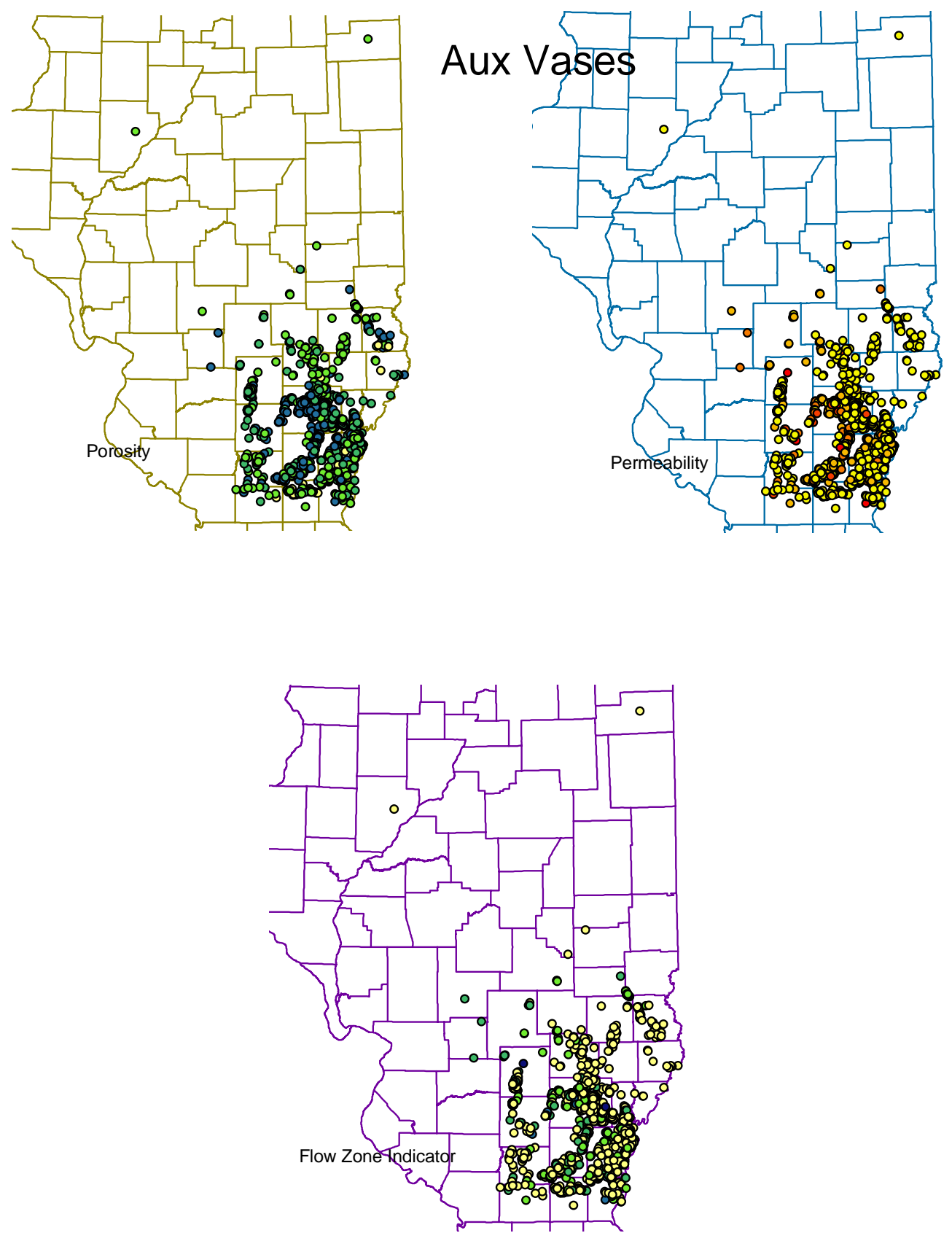

Figure 19. Wells with core analysis data of the Aux Vases Sandstone. Wells with high porosity and permeability are in red, medium values are shown in orange and low values are shown in yellow. 


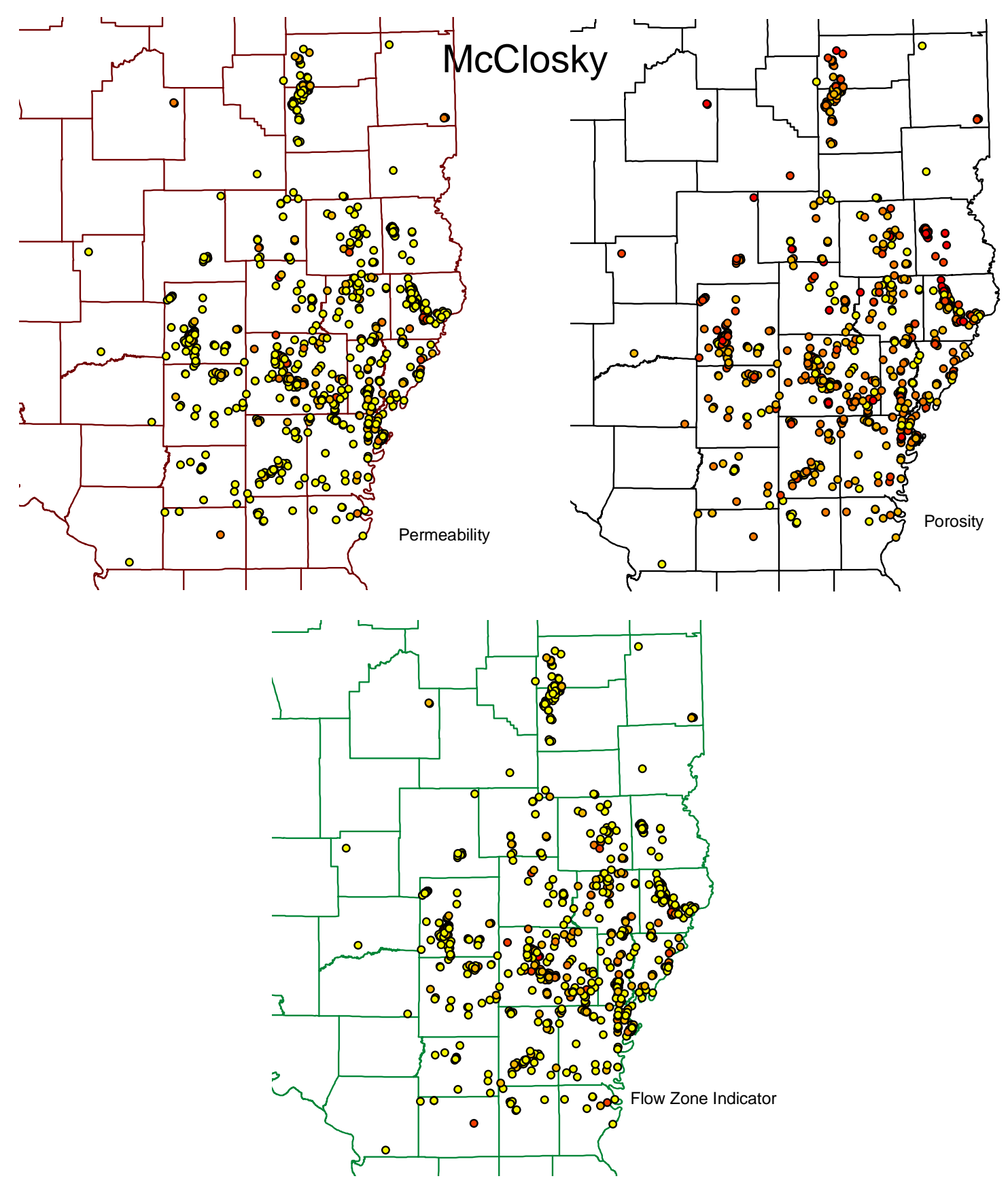

Figure 20. Wells with core analysis data from the Ste. Genevieve Formation. Wells with high porosity and permeability are in red, medium values are shown in orange and low values are shown in yellow.

Task 5 Technology Transfer. The following is a list of technology transfer activities completed for this contract. The response to the ArcIMS website following all workshops and 
presentations has been very positive. Many suggestions from users have been used to improve website features and layers. We have received many comments from independent petroleum operators that have used the website to find additional petroleum reserves. Contract databases and map products are also available in digital and paper formats by request.

\section{Technology Transfer Activities in Chronological Order}

The following contract related presentations were made at the Eastern Section AAPG Meeting held in Champaign Illinois during October 2002

Crockett, Joan E., Gustison, Steven R., Johanek, Phillip, 2002, Applications of the new"PAYZONE" GIS oil production data set in exploration and development programs in Illinois

Gustison, Steven R., Crockett, J.E., P.M. Johanek, 2002, GIS Based Mapping and Distribution of New Oil/Gas Pay Horizon Maps in Illinois

Steve Gustison, PTTC Program Manager, presented new information with regards to the current PUMP II project to over 50 attendees to the Fall Meeting of the Illinois Oil and Gas Association held in Grayville, Illinois, on November 7, 2002

A PTTC workshop on Pump II products was held on February 27, 2003 at the Illinois Oil and Gas Association Facility in Mt Vernon, Illinois. There were over 45 attendees. This workshop was presented by ISGS staff and highlighted new products including the new Interactive ILoil ArcIMS internet Map Server website of producing zone data. The Oil and Gas Interactive Map Server (IMS) website allows the public to make oil and gas well maps and tables of well names and pay zone on their computer screen. Wells can be identified according to their producing horizon. Well API number, section, township and Range, Operator Name, Farm Name and number can be identified. A listing of geophysical logs available for each well as well as a summary sheet of well activity is available on the website A CD ROM including a set of pdf files of Richard Howard's hand colored, color coded pay maps were also distributed at the workshop. This can greatly assist the Geologic Records Unit by providing operators with an accurate name and location for making data requests. Response to these new products was very positive at the workshop and at the IOGA meeting.

Contract products and the new website were highlighted at the Illinois Oil and Gas Association meeting in Evansville, IN, March 6 and 7, 2003. Computers with high speed internet connections were set-up for individual demonstrations on using the ILoil ArcIMs website at the meeting. Over 400 people attended this meeting

Technology Transfer: ISGS staff conducted on-line training sessions of the new iloil website at the Kentucky Oil and Gas Association Meeting in Louisville June 23 - 25. The meeting had over 600 attendees. 
A presentation was given on June 27, 2003 at the Independent Oil Producers Association TriState, Inc. annual meeting in Evansville, IN. This presentation discussed advances in internet delivery of data in map form and included a demonstration of how to use the new IMS website.

A synopsis on using this IMS technology was sent to the Indiana Oil and Gas Association for inclusion in their quarterly newsletter. (Gustison, Beeverson, Korose, Johanek, Cokinos, Crockett, Huff \& Seyler)

Steve Gustison spoke to the Independent Oil and Gas Association, Tri-State meeting in Evansville on June 27, 2003. The talk included a Powerpoint presentation showing how to access and use the ArcIMS site on Meltwater

A 4 hour workshop on the ILoil ArcIMs website was conducted by ISGS staff for the Midwest PTTC in conjunction with the PUMP II DOE contract on Jan. 29, 2004 at Mt Vernon, IL. The workshop had 42 industry representatives and they were shown the current status of the Waterflood data along with assistance using the ILoil IMS from the ISGS. A bank of 5 laptop computers was connected live from the Illinois Oil and Gas Association Office in Mt Vernon to our interactive mapping service. Each attendee was shown the correct way to log on and then how to use the ILoil site. Post workshop critiques contained many positive responses to having the ILoil site up and running.

ISGS staff gave formal presentations as well as individual instruction on the ArcIMS website developed presented Members of the Oil and Gas Section attended the Annual Illinois Oil and Gas Association meeting in Evansville, Indiana,March 4-6, 2004. Over 300 industry attendees were shown the ISGS ILoil IMS site and given instructions on its use. Bev Seyler and John Grube presented a talk on progress made in completing deliverables associated with the DOE contract entitled Geographic Information System Approach for Play Portfolios to Improve Oil Production in the Illinois Basin. They illustrated the ease and power of accessing oil and gas well data using the ILoil ArcIMS website and the return of map and well information files. Personal demonstrations were also available for two days at the ISGS/PTTC display booth.

A talk was presented at an ISGS Seminar April 7, 2004 entitled An Interactive ArcIMS Based Approach to Access, Display and Manipulate Geologic Data and Maps

August 8-13. Poster displaying PUMP II, lloil website and map images and concepts was presented at the Annual ESRI Convention in San Diego, CA. Poster titled GIS Approach to Improve Oil Recovery in the Illinois Basin was presented by Phil Johanek and co-authored by James Cokinos, J. Grube, B. Seyler, and B. Huff.

James S. Cokinos presented the paper "Reservoir Management Using the Illinois State Geological Survey Waterflood Database" at the Eastern Regional Meeting of the Society of Petroleum Engineers on September 17th, 2004. This paper was published in the SPE Proceedings Volume of the Eastern Regional Meeting of the Society of Petroleum Engineers

An Interactive ArclMS Based Approach to Access, Display, and Manipulate Geologic Data and Maps, B. Seyler, S. Gustison, Bryan Huff, C. Korose, Joan Crockett, Phillip Johanek and John 
Grube was presented at the Eastern Section Meeting of the American Association of Petroleum Geologists at Columbus Ohio Oct. 3-6, 2004.

\section{Conclusion}

Opportunities in Illinois for increased oil production have been constrained due to complex development histories from over a century of development of multiple stacked pays, heterogeneous reservoirs, and commingled production. To address these constraints, the Illinois State Geological Survey (ISGS) has developed a new GIS and Web delivery approach which is being successfully used to identify new fields and bypassed oil in underdeveloped areas in Illinois.

ESRI software has been used to extract and compile data from the ISGS Oracle database and to serve it in interactive map layers on a new website. The interactive maps are available to anyone with a web browser. Response to the website has been very positive.

Map layers can be manipulated to produce customized maps that meet individual user needs. Interactive maps and map layers have enhanced development and exploration capabilities in Illinois. These tools have revolutionized display and access of petroleum related data in Illinois. The combination of ArcGIS generated maps, upgrade of the ISGS Oracle database, and the implementation of ArCSDE 4.0 and ArcIMS has vastly improved the institutional capability at the ISGS to query our database, create interactive map layers and serve map and data layers over the internet.

The website has an array of interactive layers including:, Wells, Sections, Townships, Counties, Interstates, US Highways, State Highways, 7.5 Minute Quadrangle Outlines, 3 separate structure horizons, 27 separate producing horizons, Core Data, Waterflood Units and Areas, Oil Fields, Lakes, State Parks, Municipalities, Topo Maps, and DOQs. The ESRI software permits the ISGS to add scale appropriate details such as township and section lines as map magnification increases. Users need only a web browser to gain access to map and data layers. Users can turn layers on or off to create custom maps for development and exploration purposes. Map labels and titles can be added by users and page size maps can be printed off the internet if a user has a printer.

Transfer of this technology has taken place at PTTC workshops in February 2003 and January 29, 2004 in Mt. Vernon, Illinois. Both professional talks and demonstrations and numerous informal presentations and demonstrations explaining use of the website have been conducted at the Illinois Oil and Gas Association Meeting, March 5- 6, 2004 in Evansville, Indiana and at the Eastern Section AAPG Meeting, Oct. 4, 2004 in Columbus, Ohio. Participants were shown how to use the website menu bar and other website features were introduced. The website was well received and has been a popular exploration and development tool. A new computer was purchased and installed at the Illinois Oil and Gas Association office in Mt. Vernon, Illinois in August, 2004 to ease downstate access to the ILoil website.

User feedback about the website has been very positive. They find the website to be very helpful to their work in petroleum exploration and development in Illinois. Individuals have reported that the website makes it easy to survey areas for "potential interest" and that the 
capability to overlay well data on other layers is "extremely valuable" followed by statements such as "I don't know how I could continue to work in Illinois without it." Company geologists are using the website to check the accuracy and completeness of their in-house well databases and to illustrate complex, multi-pay production characteristics of prospects for inclusion in prospect reports. One individual uses the site to delineate intricate stratigraphic trends that successfully identifies new prospects. A new oil discovery attributed to the use of the lloil website verifies the success of this prospecting technique

Since the ILoil application was launched, many people have accessed the on-line mapping service. The ISGS uses WebTrends software to monitor and tabulate use of all aspects of the ISGS web page. The WebTrend analysis from December, 2003 through September, 2004 is shown in figure 21. These statistics provide an indication of how the ILoil application is being used. Statistics for Septptember, 2004 indicate that the ILoil application received 130630 hits, or about 4350 per day. The ILoil application was used by 493 unique visitors, including 285 people who used the site more than once. Perhaps most revealing is that the average visit is about 21 minutes, indicating that users are finding the site and very likely using it to access and download information. All reports from the field indicate that the oil and gas community is very satisfied with the ILoil application and the fact that the Survey is continuing to provide better access to important data holdings.

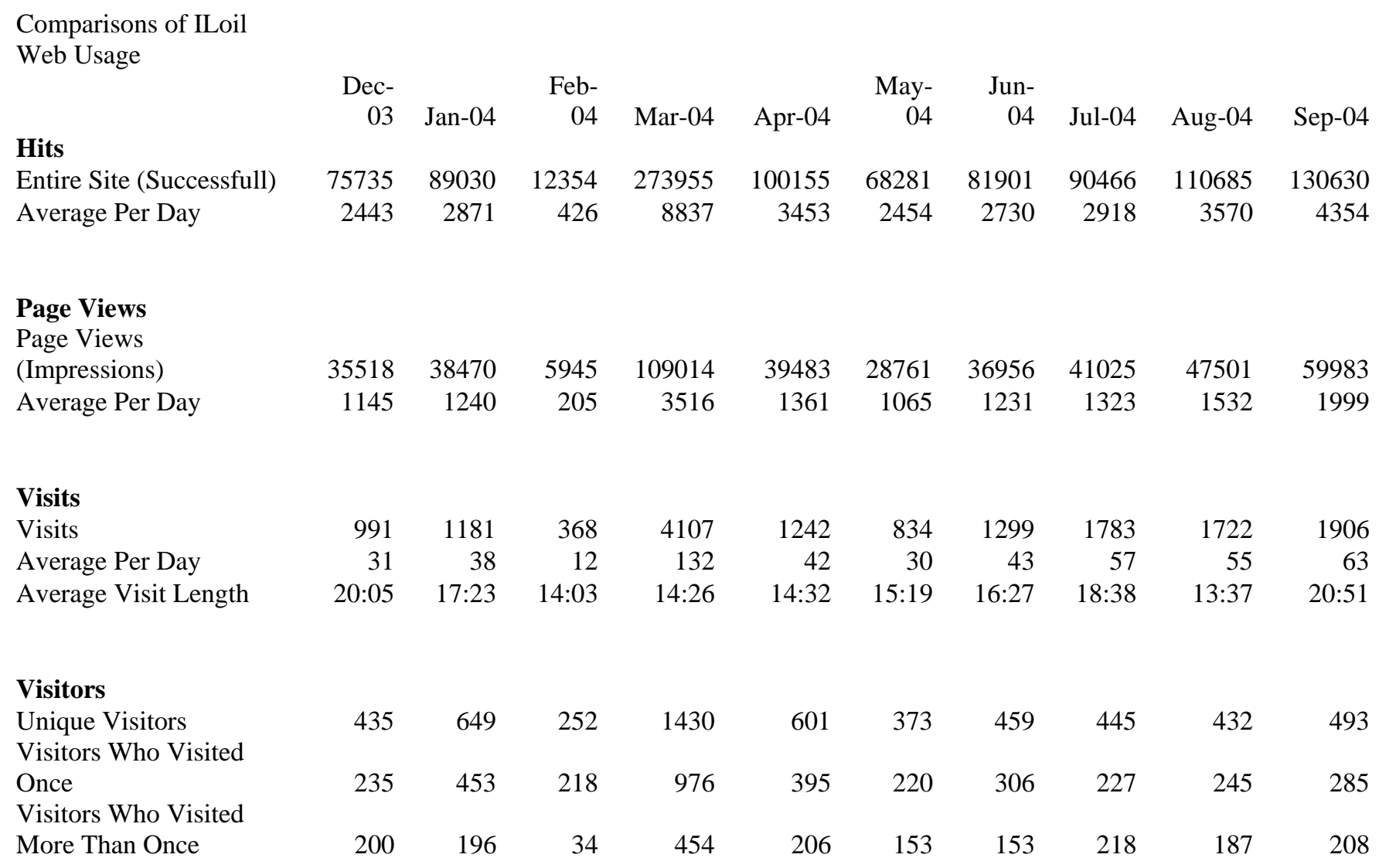

Figure 21. WebTrends statistics showing increased ILoil website usage. 
The ISGS is paying close attention to user suggestions for upgrades to the website. Upgraded versions of the website were made available in November, 2003, which included a front page and tutorial section and new layers, and in the Summer of 2004 when many more new layers were added. It is anticipated that additional data and data layers will be available in the future. The Midwest Region PTTC has offered to assist the ISGS in the maintenance of the valuable and successful ILoil website, provided that the PTTC Program is maintained.

\section{References}

No citations 


\begin{tabular}{ll}
\hline List of Acronyms and Abbreviations \\
Arc/GIS & Geographic Information System mapping software \\
Arclnfo & Geographic Mapping Software \\
ArcView & PC based geographic mapping software \\
CDs & Compact Discs \\
bpd & barrels per day \\
DOE & U. S. Department of Energy \\
GIS & Geographic Information System \\
IMS & Internet Mapping Server software \\
IOGA & Illinois Oil and Gas Association \\
ISGS & Illinois State Geological Survey \\
OOIP & Original Oil in Place \\
PMP & Preferred Management Practices \\
PTTC & Petroleum Technology Transfer Council \\
SDE & Spatial design engine for Arclnfo and ArcView products \\
UDA & Underdeveloped Area (with potential for increased production) \\
USGS & United States Geological Survey
\end{tabular}

